\title{
Plastic behavior of magnetite and high strains obtained from magnetic fabrics in the Parry Sound shear zone, Ontario Grenville Province
}

\author{
BERNARD A. HOUSEN, BEN A. VAN DER PLUIJM and ERIC J. ESSENE \\ University of Michigan, Department of Geological Sciences, 1006 C.C. Little Building, Ann Arbor, MI
} 48109-1063, U.S.A.

(Received 1 November 1993; accepted in revised form 14 March 1994)

\begin{abstract}
Magnetic anisotropy and quantitative petrology of a transition from relatively undeformed metaanorthosite protolith to highly deformed ultramylonite in the Parry Sound shear zone provide information on magnetite as a kinematic indicator. Rock magnetic experiments show that anisotropy of magnetic susceptibility (AMS) is controlled by magnetite in the mylonites and ultramylonites, and by paramagnetic minerals (hornblende, biotite, ilmenite) in the protolith. Geothermometry in the ultramylonite indicates a temperature of $630 \pm 50^{\circ} \mathrm{C}$ during deformation. A deformation mechanism map calculated from published experimental work for $630^{\circ} \mathrm{C}$ indicates that magnetite in the Parry Sound shear zone deformed plastically rather than via rigid-body rotation. The AMS orientations accurately track a foliation trajectory in a portion of the shear zone, which allows the utilization of orientation-based strain models to determine shear strains. Shear strains $(\gamma)$ of $1-9$ were obtained, and an empirical correlation of strain with the ellipsoid shape resulted in the logarithmic relationships: $M \max =0.15 \ln (X)$, and $M \min =0.13 \ln (Z)$, where $M i=(k i / k$ mean $)$ describes the principal AMS axes, or $(k \max / k \mathrm{~min})=(X / Z) 0.14$. These AMS-strain correlations were subsequently applied to mylonites and ultramylonites elsewhere in the shear zone, predicting shear strains as high as $\gamma=13$. These observations also reveal that AMS fabrics do not saturate at high strains, as would be expected for rigid-body rotation, due to the plastic behavior of magnetite during deformation.
\end{abstract}

\section{INTRODUCTION}

The study of mineral fabrics can provide information on the kinematic history of high-grade shear zones. Because mylonites in such shear zones often lack conventional strain markers and have textures that are difficult to quantify with optical methods, magnetic anisotropy has been utilized in many fabric studies of shear zones. Finite strain values (Rathore et al. 1983, Goldstein \& Brown 1988, Ruf et al. 1988) and finite strain geometries (Goldstein 1980) have been determined from magnetic susceptibility ellipsoids measured by the anisotropy of magnetic susceptibility (AMS). These correlations between AMS and strain assume rigid-particle behavior for the mineral(s) that dominate the AMS. Although the most common matrix minerals (calcite, quartz, feldspar) deform via crystal-plastic processes in high-grade mylonites (e.g. Schmid 1982, Tullis 1983), the assumption that paramagnetic silicates (hornblende, mica, pyroxene) and ferrimagnetic trace minerals (magnetite, pyrrhotite, hematite) measured by AMS behave rigidly rather than plastically in the same rocks has not been rigorously examined. Such information is, however, critical for the interpretation of magnetic fabrics in deformed high-grade rocks. To examine the behavior of the minerals which carry the magnetic susceptibility during deformation, a study of the mineralogy and AMS in a highly deformed meta-anorthosite in the Parry Sound shear zone of the mid-Proterozoic Grenville orogen in Ontario was undertaken. To constrain the behavior of these minerals, metamorphic petrology was used to determine temperature conditions during deformation, and the possible deformation mechanisms of the susceptibility carrier have been calculated from available experiments. The magnetic fabrics are interpreted in light of these results.

\section{SAMPLING AND METHODS}

The Parry Sound shear zone is a well studied Grenvillian thrust fault that separates the Parry Sound and the Britt domains in the Central Gneiss Belt of the Ontario Grenville Province (e.g. Davidson et al. 1982, White \& Mawer 1986, Gower \& Simpson 1992) (Fig. 1). On the basis of geochronologic and petrologic work (van Breeman et al. 1986, Tuccillo et al. 1992), northwest-directed thrusting of the Parry Sound domain over the Britt domain along the Parry Sound shear zone occurred under upper-amphibolite facies conditions at $c a .1120$ Ma. An exposure of deformed anorthosite in this shear zone northeast of the town of Parry Sound (Fig. 2) was selected for detailed magnetic fabric study. This outcrop preserves a transition from a coarse-grained, relatively undeformed protolith (Fig. 3a) to a finer-grained, foliated mylonite (Fig. 3b), to a highly deformed, finegrained ultramylonite (Fig. 3c). The transition from protolith to mylonite is gradual and occurs over a distance of approximately $10 \mathrm{~m}$; the transition between the mylonite and ultramylonite is sharp. From this transect (Site A) a collection of 32 oriented cores was drilled with a gas-powered portable drill. In a nearby portion of the 


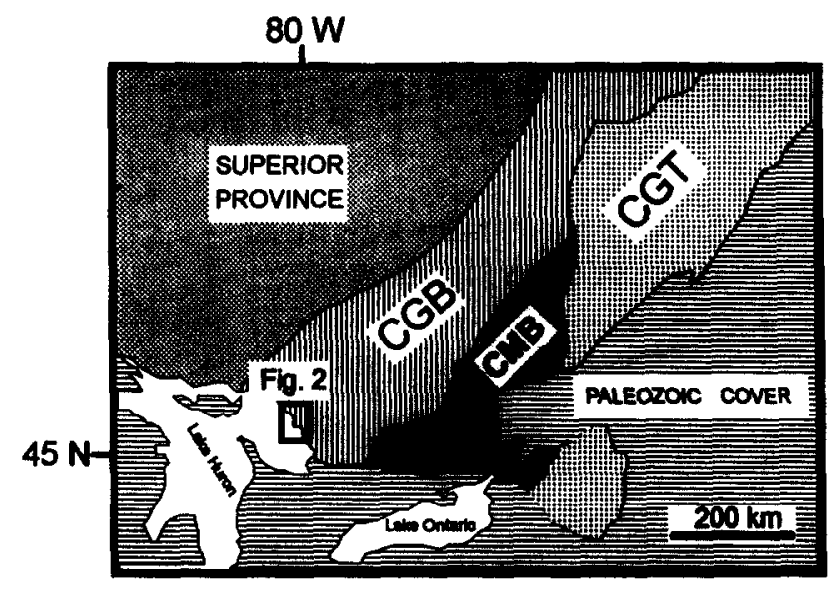

Fig. 1. Map of the Ontario Grenville Province showing lithotectonic domains (CGT, Central Granulite Terrane; CMB, Central Metasedimentary Belt; CGT, Central Gnciss Belt). Study arca in the Parry Sound shear zone is indicated.

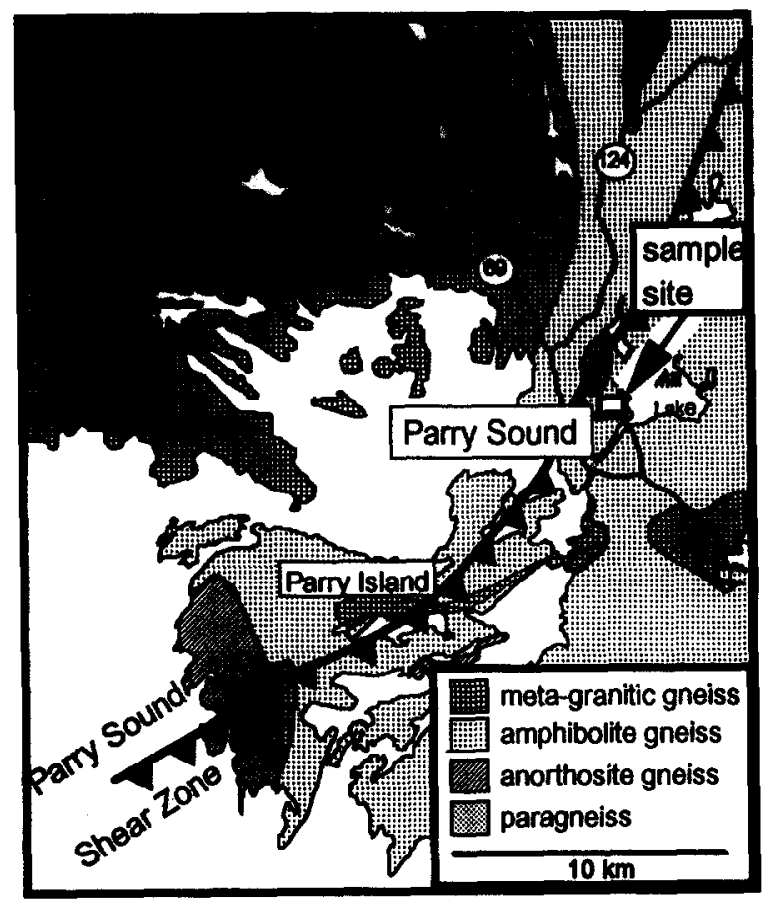

Fig. 2. Map of the Parry Sound shear zone, indicated by the thrust fault symbol, near Parry Sound, Ontario. Sample site in deformed meta-anorthosite is indicated. (Geology after Hewitt 1967).

outcrop, foliations in the mylonite deflect into the shear zone; 12 cores were collected from this location (Site B). Field measurements of foliation and lineation orientations were made in a few locations, but due to the smooth glaciated surface of the outcrop a detailed inventory of these field structures could not be made. However, as shown later, magnetic fabrics prove to be an accurate measure of these elements.

The minicores were cut into standard rock magnetic specimens ( $2.5 \mathrm{~cm}$ diameter, $2.2 \mathrm{~cm}$ long), and oriented thin sections were prepared from either chips from the excess part of the cores, or from whole specimens after measurement. Anisotropy of magnetic susceptibility (AMS) was determined using an Sl-2 induction coil (applied field $0.1 \mathrm{mT}$ at $800 \mathrm{~Hz}$ ) to measure magnetic susceptibility (low field) in six different orientations. In order to determine the contributions of paramagnetic and ferrimagnetic minerals to the measured AMS, highfield ( 0.5 to $1.4 \mathrm{~T}$ ) susceptibilities were determined using a vibrating sample magnetometer (VSM). The highfield susceptibility measures the susceptibility of the paramagnetic minerals for applied fields greater than those required to reach saturation magnetization of the ferrimagnetic phases in the sample. The ferrimagnetic portion of the susceptibility is then determined by subtracting the paramagnetic susceptibility from the measured (low-field) susceptibility. The magnetic properties of the samples were further characterized by isothermal remanent magnetization (IRM) acquisition, Curie temperature determination, and by partial anhysteretic remanent magnetization (pARM) experiments. The pARM and IRM work was conducted at the Paleomagnetic Laboratory at the University of Michigan, and the VSM and Curie temperature work was conducted at the Institute for Rock Magnetism at the University of Minnesota.

Examination of polished thin sections using transmitted light microscopy aided in determining the mineralogy and microstructures of the samples. Identity, morphology and size of the opaque phases were determined using reflected light microscopy. Scanning electron microscopy (SEM) provided additional characterization of these minerals. Mineral compositions were determined from results measured on a Cameca Camebax electron microprobe using a wavelength-dispersive analysis (WDA) system. The results were obtained using a mixture of natural and synthetic mineral standards, operating voltage of $15 \mathrm{kV}$, $10 \mathrm{nA}$ sample current, and analysis software provided by Cameca. Garnet, magnetite, and ilmenite were analyzed using a spot beam; feldspars and amphiboles were analyzed using a rastered $\left(9-\mu \mathrm{m}^{2}\right.$ area) beam to minimize Na loss during measurement.

\section{RESULTS}

\section{Matrix fabric}

Mineral textures observed via optical microscopy are used to characterize the progression and nature of deformation in these rocks. In all cases the matrix mineralogy is predominantly plagioclase, $\mathrm{K}$-feldspar and quartz. The protolith samples contain coarse $(100$ to $>500 \mu \mathrm{m})$, equant grains with stable grain-boundary textures (Fig. 4a). The plagioclase feldspars display abundant albite twins. The protolith is moderately foliated, with hornblende and biotite defining the foliation. In thin section, mylonite samples show a marked reduction in matrix grain size (50-150 $\mu \mathrm{m})$, and a foliation defined by hornblendes, elongate feldspars and quartz (Fig. 4b). Only rarely are twinned plagioclase grains found, and close examination of plagioclase reveals abundant subgrains. The reduction in grain size, grain elongation, and presence of subgrains indicate that the matrix feldspar 
Plastic behavior of magnetite in the Parry Sound shear zone
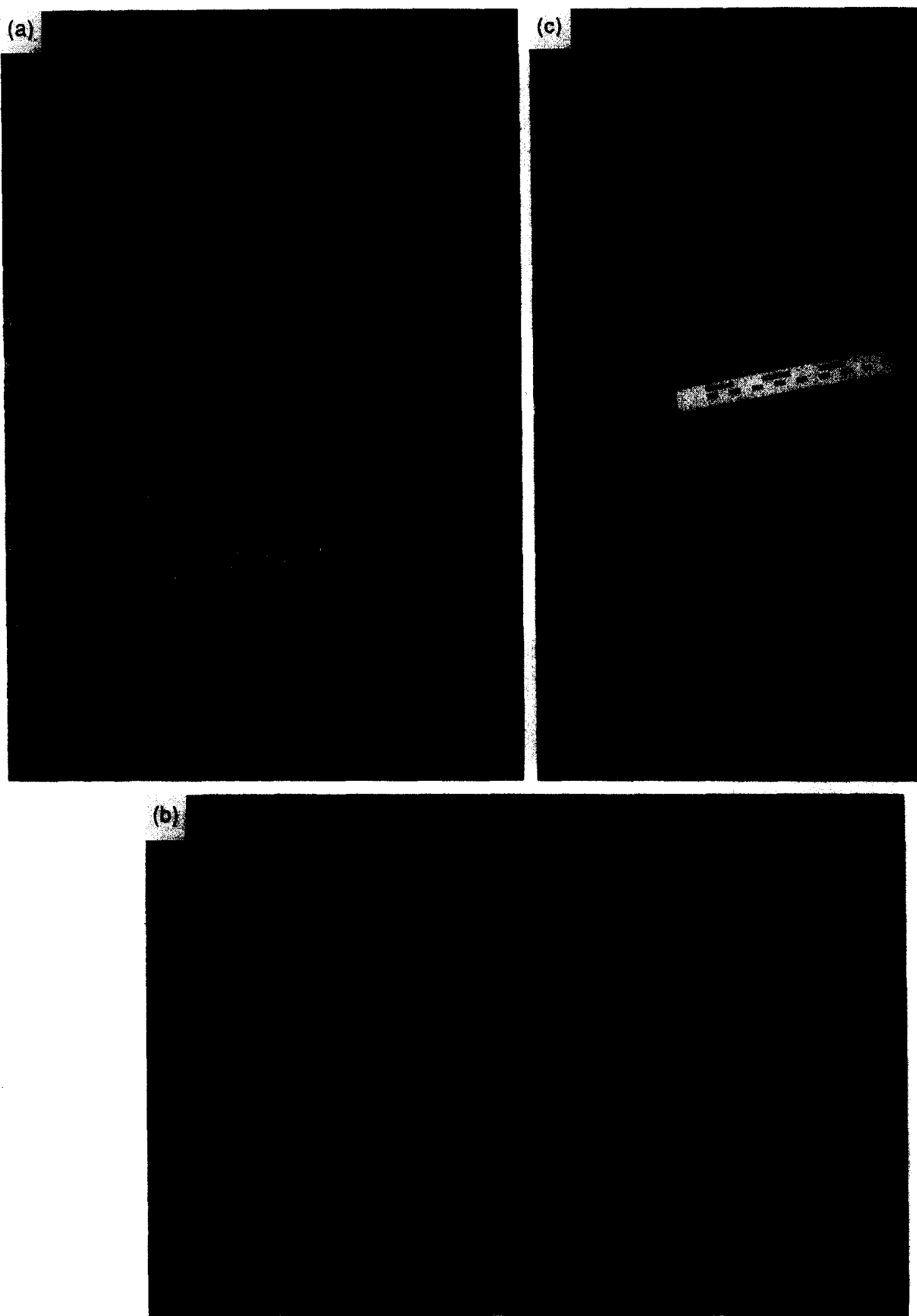

Fig. 3. Outcrop photographs of (a) protolith, (b) mylonite, and (c) ultramylonite sample locations at Site A. The distance between each photograph is approximately $10 \mathrm{~m}$. 
B. A. HOUSEN, B. A. VAN DER PLUIJM and E. J. ESSENE

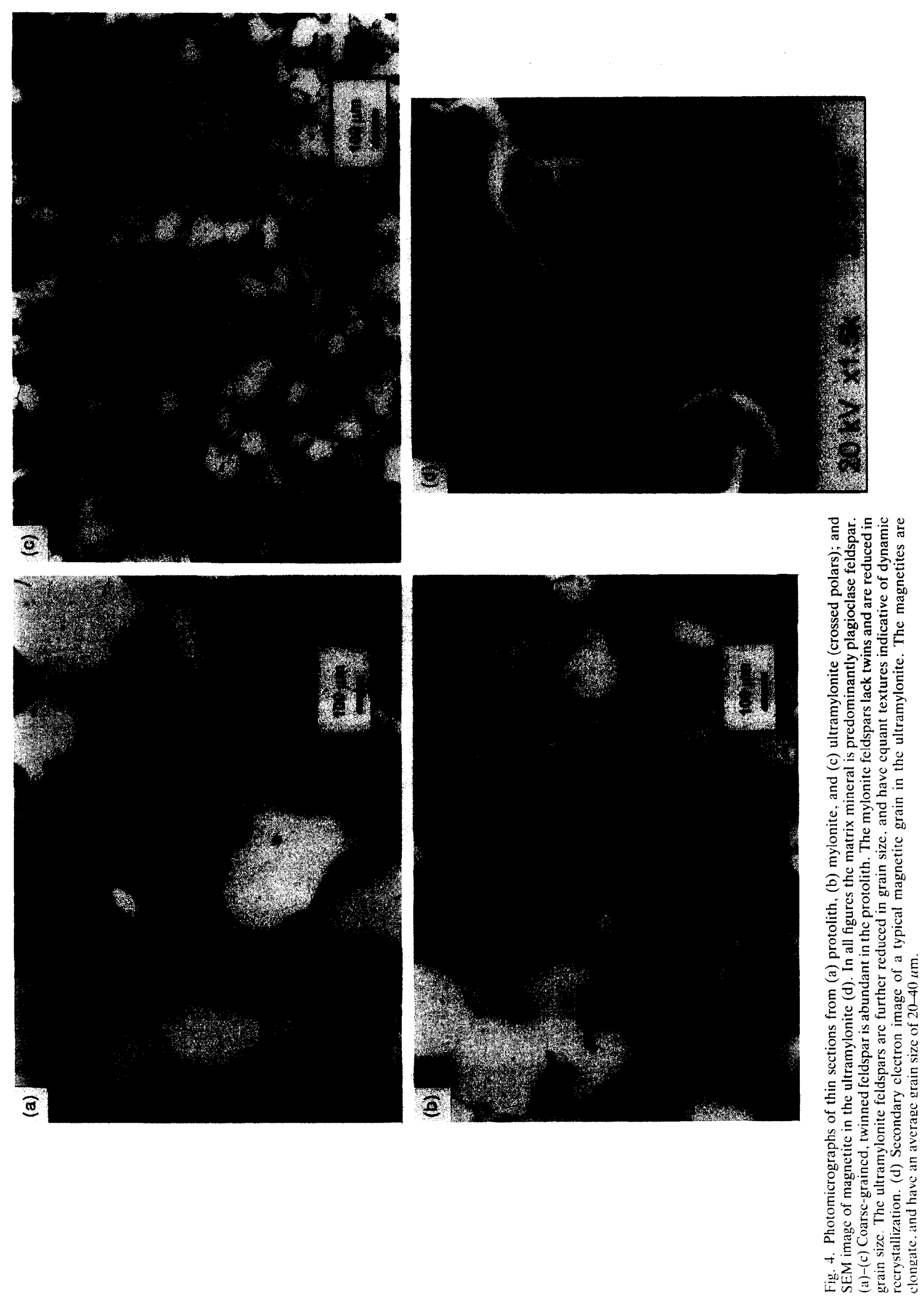




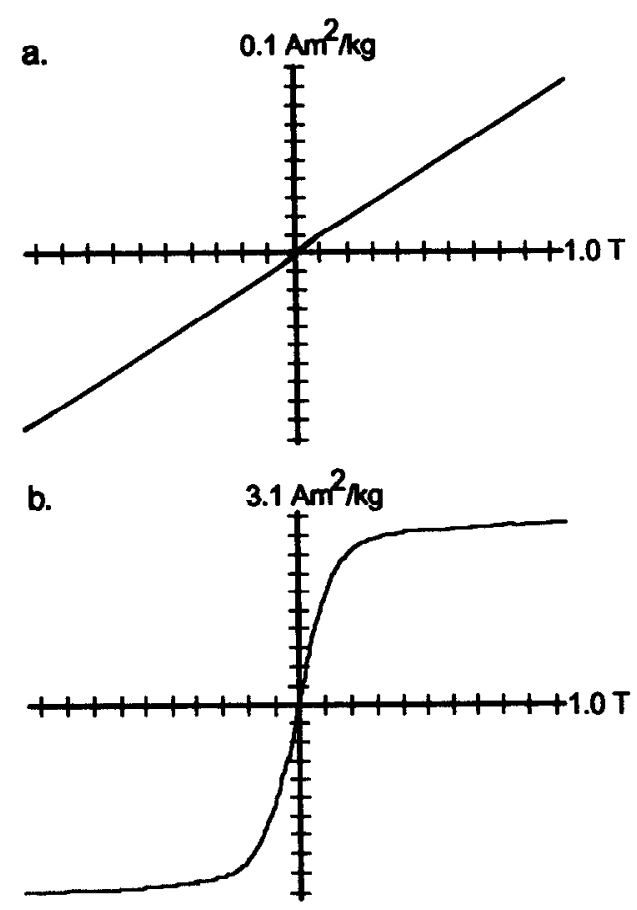

Fig. 5. Hysteresis curves from protolith (a) and ultramylonite (b) samples showing high-field susceptibility behavior. The vertical axis is magnetization $\left(\mathrm{Am}^{2} \mathrm{~kg}^{-1}\right)$ of the sample; the horizontal axis is applied field $(\mathrm{T})$. The slope of the curve at fields above $0.3 \mathrm{~T}$ is proportional to the paramagnetic susceptibility.

deformed by crystal-plastic processes (Tullis \& Yund 1985, Knipe 1989). Ultramylonites are greatly reduced in grain size $(20<100 \mu \mathrm{m})$, with equant, polygonal matrix feldspar and quartz (Fig. 4c). These textures are consistent with other observations of dynamically recrystallized feldspar in ultramylonites (Tullis \& Yund 1985). White \& Mawer (1986) and Gower \& Simpson (1992) similarly concluded that matrix feldspar and quartz in the Parry Sound shear zone deformed via crystal plasticity and diffusional creep. Other phases in these rocks (hornblende, clinozoisite, ilmenite, magnetite, garnet) show similar reduction in grain size, with the exception of rare, large $(>150 \mu \mathrm{m})$ garnets in the ultramylonite.

\section{Magnetic mineralogy}

High-field susceptibility results indicate that $>90 \%$ of the magnetic (low-field) susceptibility in the protolith samples is carried by paramagnetic minerals, and that $>90 \%$ of the low-field susceptibility of the mylonites and ultramylonites is carried by ferrimagnetic minerals (Fig. 5). Petrographic observations reveal that hornblende, biotite, and ilmenite are the principal paramagnetic minerals in the protolith. The AMS results from the protolith therefore reflect the crystallographic preferred orientation of these minerals. Further rock magnetic tests were needed to characterize the ferrimagnetic trace minerals in the mylonite and ultramylonite. The IRM acquisition experiments found that saturation magnetization was obtained by $0.1 \mathrm{~T}$ (Fig. 6). This rules out the presence of significant hematite, goethite, or finegrained pyrrhotite. Whole-rock Curie temperature experiments gave stable, reversible heating and cooling

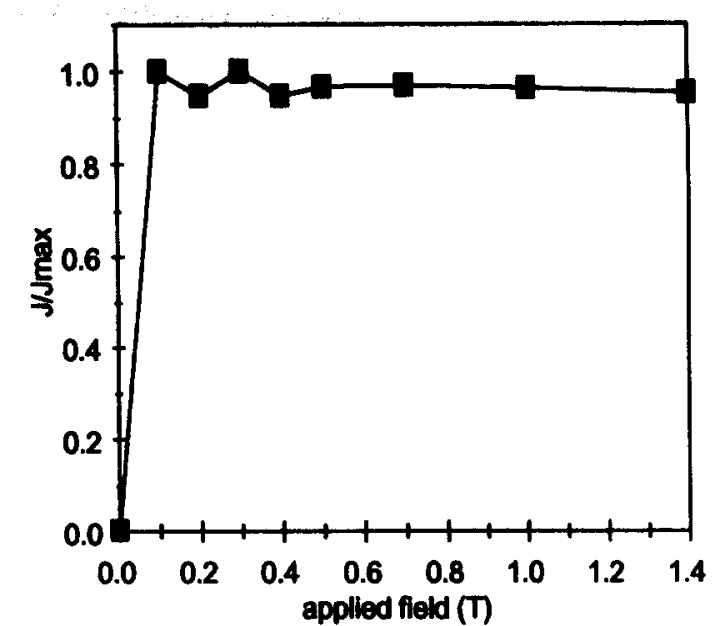

Fig. 6. Acquisition of isothermal remanent magnetization from a typical ultramylonite sample. The vertical axis is normalized magnetization; the horizontal axis is applied field.

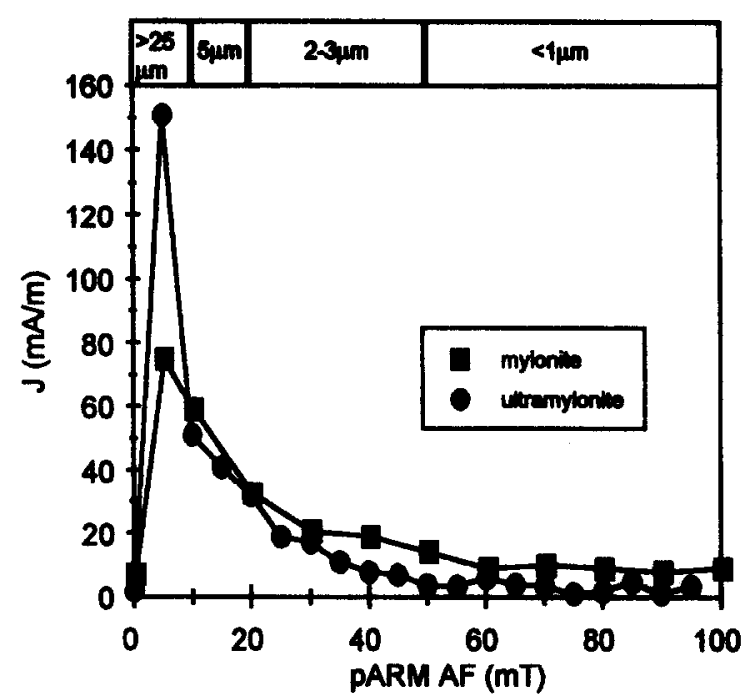

Fig. 7. Acquisition of partial anhysteretic remanent magnetization for representative mylonite and ultramylonite samples. The vertical axis is magnetization $(\mathrm{mA} / \mathrm{m})$, and the horizontal axis is the intensity of the AF used for the PARM step (mT). A pARM window $10 \mathrm{mT}$ wide with a DC field of $0.1 \mathrm{mT}$ was used for each step. Magnetite grain sizes $(\mu \mathrm{m})$ for given coercivity values are provided at the top of the plot.

runs, with a $T_{\mathrm{c}}$ of $565^{\circ} \mathrm{C}$. The IRM and Curie temperature experiments indicate that magnetite is the only significant ferrimagnetic mineral in these rocks. The AMS of the mylonites and ultramylonites therefore records the dimensional preferred orientation of magnetite in the shear zone.

Magnetite grain size was determined by stepwise pARM, finding peak coercivities at $5 \mathrm{mT}$ (Fig. 7), which indicates an average magnetite grain size $>25 \mu \mathrm{m}$ in the mylonites and ultramylonites (Jackson et al. 1988). The mean grain size from reflected light measurements of magnetite grains in the mylonites and ultramylonites is $40 \mu \mathrm{m}$, which is consistent with that obtained by pARM. Magnetite grain shapes were also determined from reflected light microscopy measurements of 50 grains (each) in mylonite and ultramylonite samples, and from SEM observations (Fig. 4d). The magnetite grains are elongate, with an average length/width ratio of 3 . 

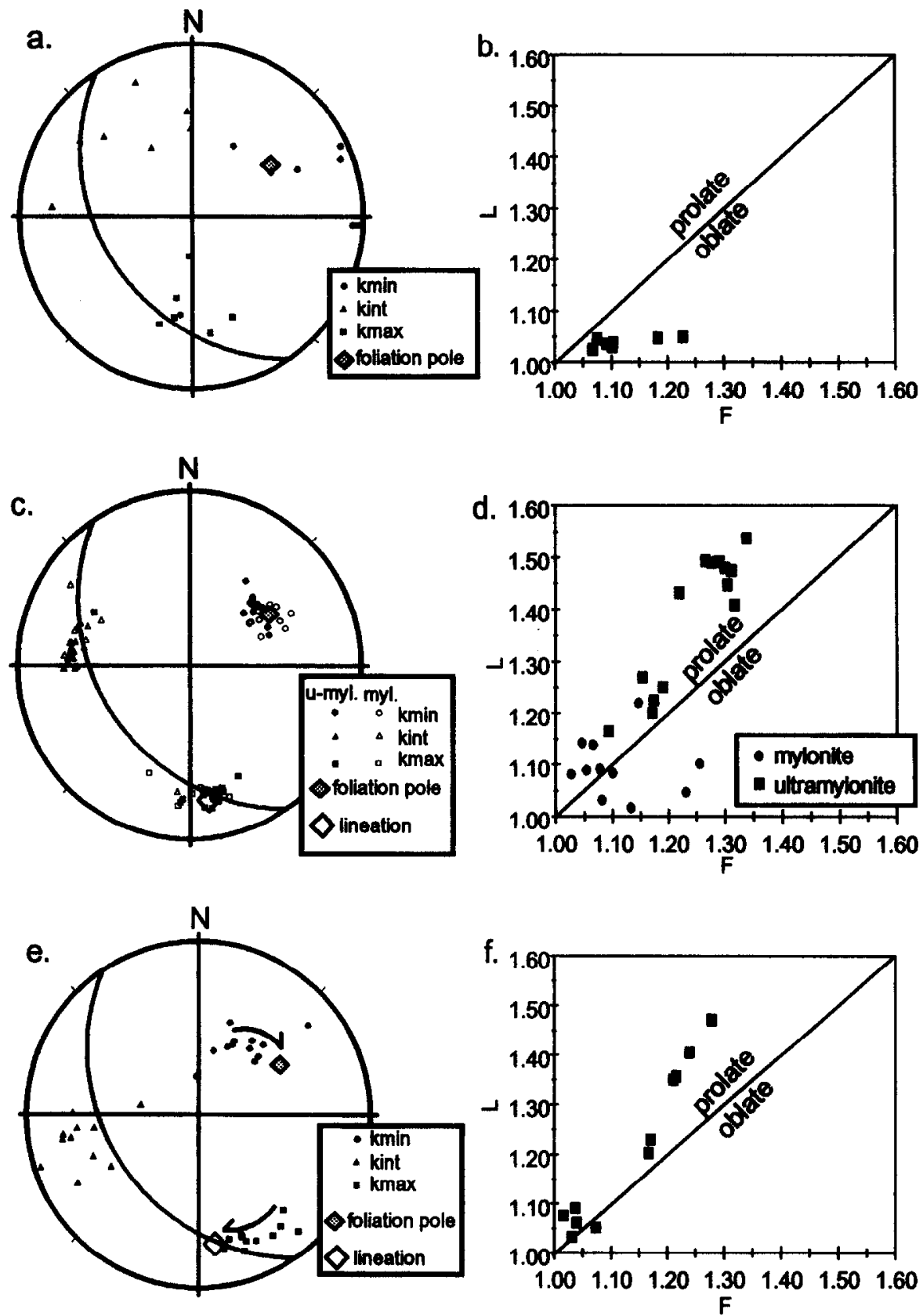

Fig. 8. AMS results from the Parry Sound shear zone. Orientations of the principal susceptibility axes are plotted on lower-hemisphere stereograms, along with the observed shear zone foliation (great-circle, pole is diamond), and lineation (open diamond). The orientations of the shear zone foliation and lineation are the same at hoth Sites A and B. Flinn-type diagrams are used to describe the shape of the AMS ellipsoids. The vertical axis is magnetic lineation $\left(L=k_{\max } / k_{\text {int }}\right)$; the horizontal axis is magnetic foliation $\left(F=k_{\text {int }} / k_{\min }\right)$. Results with $L>F$ have prolate AMS ellipsoids, results with $L<F$ have oblate ellipsoids. (a) Orientations of AMS axes for the protolith samples at Site A. The AMS axes are scattered about the observed foliation. (b) The shape of the protolith AMS ellipsoids are oblate. (c) AMS orientations for mylonite (open) and ultramylonite (filled) samples from Site $\mathrm{A}$. The orientations match the observed petrofabric information, with $k_{\min }$ at the pole to foliation, the $k_{\max }-k_{\text {int }}$ plane parallel to the foliation planc, and $k_{\max }$ parallcl to the lineation in the ultramylonites. (d) The shapes of the susceptibility ellipsoids change from weakly anisotropic in the mylonites to highly anisotropic and prolate in the ultramylonites. The trend in shapes parallels the plane-strain line of the Flinn diagram. (e) AMS orientations from mylonites and ultramylonites from Site $B$. The orientations track a progressive deflection of mylonite foliation and lineation into the shear-zone foliation/lineation (trend shown by arrows). (f) The shapes of the susceptibility ellipsoid for these samples show a trend towards highly anisotropic, prolate shapes in the ultramylonites similar to the situation for Site A.

\section{Magnetic fabrics: protolith}

Anisotropy of magnetic susceptibility (AMS) results for the protolith do not agree well with the weak mesoscopic fabric. The orientations of the principal susceptibility axes $\left(k_{\max }, k_{\text {int }}, k_{\min }\right)$ are scattered. The $k_{\min }$ axes are broadly scattered about the pole to foliation, and the $k_{\text {max }}$ axes fall near the field-observed lineation (Fig. 8a).
The shape of the susceptibility ellipsoid is oblate (Fig. $8 b)$.

\section{Magnetic fabrics: mylonite and ultramylonite}

Several striking results were obtained from AMS measurements of the mylonites and ultramylonites. First, a large increase in the mean volume susceptibility 
from $3 \times 10^{-4}$ in the mylonites to $7 \times 10^{-2}$ in the ultramylonites was found (Table 1). Because the susceptibility is carried by magnetite the relationship between magnetite content and susceptibility, $k_{\text {mean }}$ (SI volume units) $\approx 3 \times$ magnetite volume fraction (Mooney \& Bleifuss 1953), can be used. Thus, the change in susceptibility corresponds to an increase in magnetite volume from $0.01 \%$ in the mylonites to $1-2 \%$ in the ultramylonites. This increase in magnetite abundance is consistent with thin section and SEM estimates of the modal mineralogy.

The orientations of the AMS axes correspond well to the observed rock fabrics: $k_{\min }$ is parallel to the pole to foliation, $k_{\max }$ and $k_{\text {int }}$ in the plane of foliation with $k_{\max }$ parallel to the observed lineation direction (Fig. 8c). The shape of the susceptibility ellipsoid changes from moderately anisotropic in the mylonites to highly anisotropic and strongly prolate in the ultramylonites (Fig. 8d).

Mylonites at Site B nearest the ultramylonites have $S$ foliations that are sub-parallel to the $C$ foliation, with the angle between the $S$ and $C$ foliations decreasing when moving toward the ultramylonites. The AMS results from these samples capture this trend, with magnetic foliations trending from 193/31 (dip direction/ dip) in the sample farthest from the ultramylonite, to 225/35 (dd/d) nearest the ultramylonite (Fig. 8e). The shape of the susceptibility ellipsoid correspondingly trends from weakly anisotropic to highly prolate nearest the ultramylonite zone (Fig. 8f).

\section{Petrography}

The protolith contains the mineral assemblage plagioclase $\left(\mathrm{An}_{50}\right)+$ hornblende + garnet + clinozoisite + biotite + ilmenite + quartz + sphene + K-feldspar + pyrite + magnetite \pm monazite \pm zircon. The mylonite contains the mineral assemblage plagioclase $\left(\mathrm{An}_{35-45}\right)+$ K-feldspar + hornblende + quartz + garnet + clinozoisite + ilmenite + pyrite + magnetite \pm sphene \pm zircon. The ultramylonite contains the texturally stable assemblage plagioclase $\left(\mathrm{An}_{20-30}\right)+\mathrm{K}$-feldspar + hornblende + quartz + garnet + clinozoisite + ilmenite + pyrite + magnetite \pm sphene \pm monazite \pm allanite \pm zircon \pm sphalerite. With increasing mylonitization plagioclase and its anorthite content decreases in relative abundance, and magnetite, $\mathrm{K}$-feldspar, and quartz increase in relative abundance. Biotite is found in the protolith but is absent in the mylonites and ultramylonites. These changes in mineralogy with mylonitization suggest the operation of two possible reactions:

$$
\begin{aligned}
& 2 \mathrm{~K}(\mathrm{Fe})_{3} \mathrm{AlSi}_{3} \mathrm{O}_{10}(\mathrm{OH})_{2}+\mathrm{O}_{2} \\
& \quad \mathrm{Fe}-\text { biotite } \\
& =\underset{\text { Sanidi }}{2 \mathrm{O}_{8}}+2 \mathrm{Fe}_{3} \mathrm{O}_{4}+2 \mathrm{H}_{2} \mathrm{O} \\
& \quad \text { sanidine magnetite }
\end{aligned}
$$

(reaction 1)

(Wones \& Fugster 1965); and:

$$
6 \mathrm{CaAl}_{2} \mathrm{Si}_{2} \mathrm{O}_{8}+3 \mathrm{Ca}_{2} \mathrm{Fe}_{5} \mathrm{Si}_{8} \mathrm{O}_{22}(\mathrm{OH})_{2}
$$$$
\text { anorthite ferroactinolite }
$$

$$
\begin{aligned}
& =2 \mathrm{Ca}_{3} \mathrm{Al}_{2} \mathrm{Si}_{3} \mathrm{O}_{12}+\mathrm{Fe}_{3} \mathrm{Al}_{2} \mathrm{Si}_{3} \mathrm{O}_{12} \\
& \text { grossular almandine } \\
& +3 \mathrm{Ca}_{2} \mathrm{Fe}_{3} \mathrm{Al}_{4} \mathrm{Si}_{6} \mathrm{O}_{22}(\mathrm{OH})_{2}+18 \mathrm{SiO}_{2} \\
& \text { ferrotschermakite quartz }
\end{aligned}
$$

(Kohn \& Spear 1990). Both reactions are consistent with the observed loss of biotite and Ca-rich feldspar from the protolith, and increase in $\mathrm{K}$-feldspar, magnetite and quartz in the more deformed rocks, but more complex reactions involving other minerals are also possible. In addition, preliminary $\mathrm{X}$-ray fluorescence data indicate that the ultramylonite is metasomatically altered compared to the mylonite and protolith (Housen 1994).

\section{Geothermometry}

Minerals in the ultramylonite have straight, polygonal grain boundaries and show other features indicative of textural equilibrium among the mineral phases. Mineral assemblages available for geothermometry in these rocks include: amphibole-plagioclase (Blundy \& Holland 1990), garnet-amphibole (Graham \& Powell 1984) and garnet-ilmenite (Pownceby et al. 1991). Before application of the amphibole geothermometers, difficulties arising from the use of differing normalization methods in amphiboles need to be considered. In the absence of wet-chemical data the $\mathrm{Fe}^{3+} / \mathrm{Fe}^{2+}, \mathrm{OH}$, and $\mathrm{O}$ contents of any amphibole are unknown so any cationor anion-based normalization scheme will not be able to provide a unique composition. An evaluation of the various normalization schemes using amphiboles of known composition found that the 13 small cation method produced the most accurate $\mathrm{Fe}^{3+} / \mathrm{Fe}^{2+}$ values (Cosca et al. 1991). Because all amphibole-based thermometers are empirical, the same normalization method used in the initial calibration must be maintained. These geothermometers use less accurate normalization schemes (such as $23 \mathrm{O}$ ) to determine $\mathrm{Fe}^{3+} / \mathrm{Fe}^{2+}$, which introduces an additional degree of uncertainty, especially for Fe-rich amphiboles.

Amphibole-plagioclase and garnet-amphibole temperatures. Amphiboles in all the rocks are unzoned and show increases in $\mathrm{Fe}$ content and decreases in $\mathrm{Al}, \mathrm{Mg}$ content from the protolith to the mylonite (Table 2). All of the amphiboles have high (>17 wt. \%) Fe, and unusually high (1.8-2 wt. \%) $\mathrm{K}_{2} \mathrm{O}$ contents which correspond to $c a .40 \%$ A-site occupancy. Using the 13 small cation normalization method, 2-6 wt. $\% \mathrm{Fe}_{2} \mathrm{O}_{3}$ is obtained. Plagioclase associated with amphiboles are weakly zoned ( $\sim 1-4 \mathrm{~mol} \%$ increase in $\mathrm{Ab}$ from core to rim) and have much higher $\mathrm{Na}$ content in the ultramylonite $\left(A b_{75-80}\right)$ than in the protolith $\left(A b_{38-45}\right)$ (Table 2$)$. Garnets in the ultramylonite have slightly higher grossu$\operatorname{lar}\left(\mathrm{Gro}_{30-35}\right.$ vs $\left.\mathrm{Gro}_{25-30}\right)$ and almandine $\left(\mathrm{Alm}_{58-67}\right.$ vs $\left.\mathrm{Alm}_{55-60}\right)$ contents relative to those in the protolith (Table 2). The garnets in the protolith have moderate retrograde zonation and those in the ultramylonite are generally unzoned. Ilmenites are weakly zoned or 


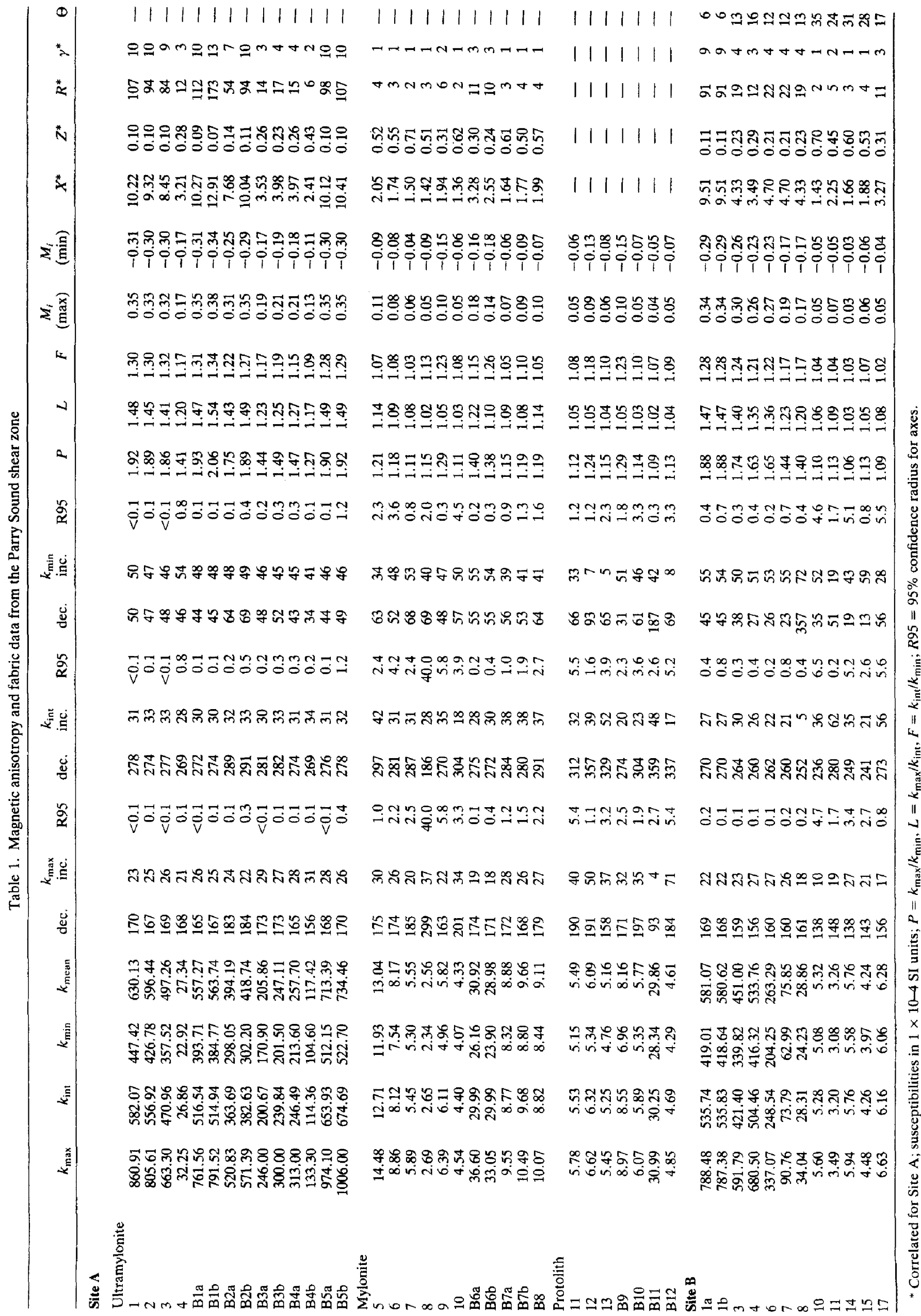


Table 2. Representative mineral compositions

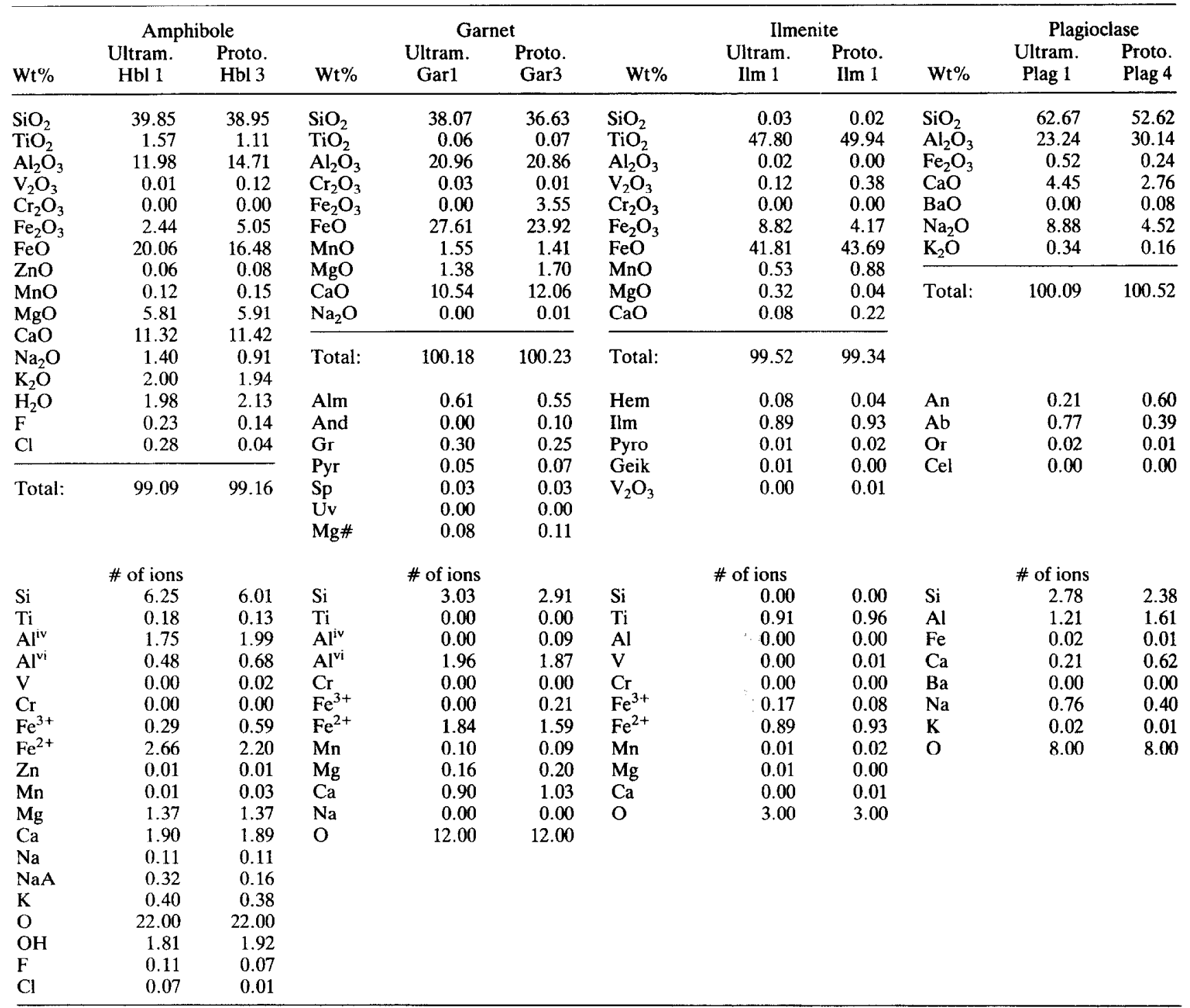

unzoned in the ultramylonite and the protolith, and increase in hematite component from $\mathrm{Hem}_{2-6}$ in the protolith to $\mathrm{Hem}_{5-10}$ in the ultramylonite (Table 2).

Blundy \& Holland (1990) presented three possible models to calculate temperatures from $\mathrm{Na}$ and $\mathrm{Al}$ contents of coexisting amphibole and plagioclase. They estimated $\mathrm{Fe}^{3+}$ from the normalization technique of Spear \& Kimball (1984) which uses an 'average' $\mathrm{Fe}^{3+}$ content determined from several different normalization methods. Using this normalization method $\mathrm{Fe}^{3+} / \mathrm{Fe}^{2+}$ values of $0.05-0.25$ are calculated for the Parry Sound amphiboles. The more accurate method of Cosca et al. (1991) produces $\mathrm{Fe}^{3+} / \mathrm{Fe}^{2+}$ values ranging from 0.1 to 0.3 for the same amphiboles. Although $\mathrm{Fe}^{3+}$ does not explicitly appear in the temperature calculation of Blundy \& Holland (1990), the different estimates of $\mathrm{Fe}^{3+}$ result in small but significant differences in the $\mathrm{Na}$, $\mathrm{Al}$, and $\mathrm{Si}$ contents which are used in the geothermometer. The calculation preferred by Blundy \& Holland (1990) assumes that the $\mathrm{K}$ content of amphiboles is negligible relative to $\mathrm{A}$-site $\mathrm{Na}$ content. This is clearly not the case in the Parry Sound amphiboles, so we used one of their alternate models that uses both $\mathrm{K}$ and $\mathrm{Na}$ to determine the amphibole A-site vacancy. A tempcrature of $630 \pm 50^{\circ} \mathrm{C}$ is obtained from ten amphiboleplagioclase pairs in the ultramylonite, and a temperature of $600 \pm 50^{\circ} \mathrm{C}$ is calculated from six amphiboleplagioclase pairs in the protolith.

Graham \& Powell (1984) developed a garnetamphibole $\mathrm{Fe} / \mathrm{Mg}$ thermometer. Amphibole compositions for this thermometer were calculated using a $23 \mathrm{O}$ normalization scheme, which of necessity assumes that all $\mathrm{Fe}$ is $\mathrm{Fe}^{2+}$. Temperatures from the ten garnetamphibole pairs in the ultramylonite are $660 \pm 50^{\circ} \mathrm{C}$ and $720 \pm 50^{\circ} \mathrm{C}$ from the six garnet-amphibole pairs in the protolith. Graham \& Powell (1984) cautioned that high values of unaccounted for $\mathrm{Fe}^{3+}$ would result in anomalously high temperatures using their method. The higher temperatures in the protolith are likely due to the effect of unaccounted for $\mathrm{Fe}^{3+} / \mathrm{Fe}^{2+}$ values of $0.2-0.3$ in these amphiboles.

Garnet-ilmenite temperatures. Pownceby et al. (1991) developed a geothermometer based on Fe/Mn exchange between coexisting garnet and ilmenite. Garnets in both the protolith and ultramylonite have low Mn cores and 
Table 3. Constitutive equations for magnetite deformation mechanisms

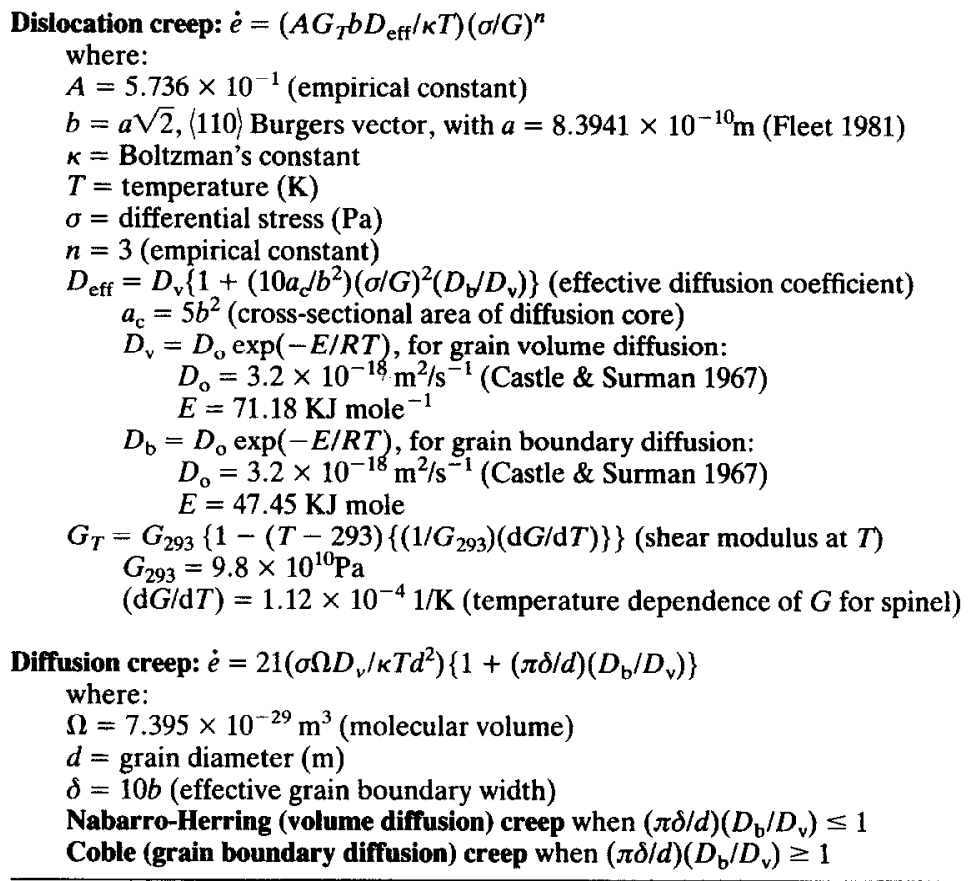

Values from Atkinson (1977) unless otherwise indicated.

higher $\mathrm{Mn}$ rims, which is a common feature of retrograde garnets (Spear 1991). Using six matrix ilmenites (surrounded only by feldspar and/or quartz to minimize Mn diffusion with other minerals) and nearby garnets in the ultramylonite, temperatures of $630 \pm 50^{\circ} \mathrm{C}$ were obtained from garnet cores and matrix ilmenite, and $<550^{\circ} \mathrm{C}$ using garnet rims and matrix ilmenite. Highly variable results were obtained using garnet-ilmenite pairs in which $<0.5 \mathrm{wt}$. \% $\mathrm{MnO}$ was present in the ilmenite. Temperatures obtained from garnets touching adjacent ilmenites with $>0.5 \mathrm{wt}$. $\% \mathrm{MnO}$ were all 450 $570^{\circ} \mathrm{C}$. Although Pownceby et al. (1991) downplayed the effect of rapid $\mathrm{Mn}$ diffusion, these results suggest that Mn in garnet-ilmenite pairs is reset by diffusion during retrogression. This is similar to the resetting of garnetbiotite temperatures due to rapid $\mathrm{Mg}$ diffusion in biotite/ garnet pairs (Indares \& Martignole 1985).

\section{DISCUSSION}

In order to properly evaluate the AMS results, the behavior of magnetite in the Parry Sound shear zone during deformation must be considered. First, the increase in magnetite volume indicated by susceptibility measurements and petrographic observation may imply that magnetite growth occurred in the mylonites and ultramylonites. Although a possible magnetite forming reaction is identified (reaction 1), only the increase in magnetite volume between the protolith and the mylonites can be accounted for by this reaction because biotite is found exclusively in the protolith. Alternatively, magnetite may have concentrated passively. This concentration mechanism is commonly associated with large volume loss during mylonitization in shear zones
(O'Hara 1990). Preliminary whole-rock geochemical results from the Parry Sound shear zone suggest that volume loss of some constituents occurred in the ultramylonites, but this requires further work (Housen 1994).

The second consideration is the expected behavior of magnetite grains during deformation. To evaluate the rheologic behavior of magnetite, a deformation mechanism map was calculated from published constitutive equations that are listed in Table 3 . Three deformation mechanisms are important: high-temperature powerlaw creep (dislocation creep), Nabarro-Herring creep (volume diffusion creep), and Coble creep (grainboundary diffusion creep) (Atkinson 1977). Using $T=630 \pm 50^{\circ} \mathrm{C}$ obtained from geothermometry as the temperature during mylonitization, the corresponding deformation mechanism map is shown in Fig. 9. Strainrate $(\dot{e})$ contours from $1 \times 10^{-7} \mathrm{~s}^{-1}$ to $1 \times 10^{-16} \mathrm{~s}^{-1}$ were determined by solving the constitutive equations for the desired strain rate by varying either grain size or differential stress. To obtain the dominant deformation mechanism(s) for magnetite in the Parry Sound shear zone, grain size as well as either stress, or strain rates, must be estimated. The magnetites in the Parry Sound shear zone are $20-40 \mu \mathrm{m}$ in size. Differential stresses of 10-100 MPa are typical for quartzo-feldspathic rocks at mid-crustal levels in orogenic belts (e.g. Etheridge 1983), so dislocation creep is the dominant deformation mechanism of magnetite (Fig. 9). The associated strain rate during mylonitization ranges from $1 \times 10^{-9}$ to $1 \times 10^{-12} \mathrm{~s}^{-1}$. This range lies on the high end of strain rates reported from other orogenic belts, but agrees with other studies on mylonites (Pfiffner \& Ramsay 1982, Schmid 1989). Moreover, because magnetite is an accessory phase, the rheology of the matrix minerals (quartz, 


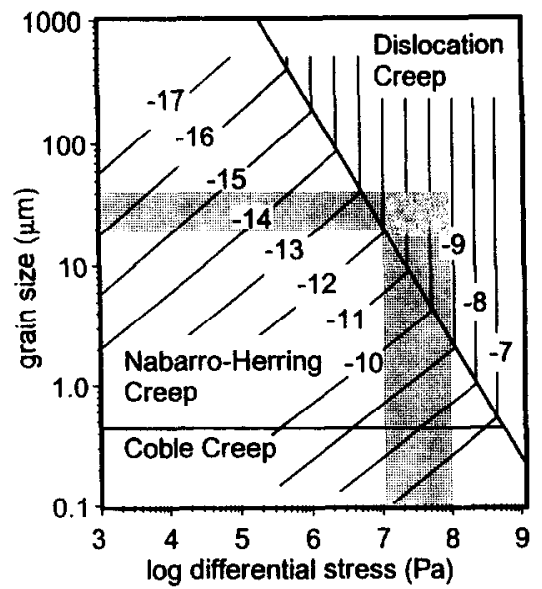

Fig. 9. Deformation mechanism map of magnetite calculated from the constitutive equations in Table 3 for a temperature of $630^{\circ} \mathrm{C}$. The vertical axis is $\log$ grain size $(\mu \mathrm{m})$, the horizontal axis is $\log$ differential stress (Pa). Strain rate contours from $1 \times 10^{-7}$ to $1 \times 10^{-17}\left(\mathrm{~s}^{-1}\right)$ are plotted and labeled with the exponent. Magnetite grain size from pARM and microscopy $(20-40 \mu \mathrm{m})$, and stresses (10-100 MPa) thought to be typical of orogenic belts are shaded. These values indicate that magnetite deforms via dislocation creep, and is capable of $1 \times 10^{-9}$ to $1 \times 10^{-12}\left(\mathrm{~s}^{-1}\right)$ strain rates.

feldspar) will control the bulk strain rate in the shear zone.

\section{AMS-strain correlations}

The response of minerals to strain in rocks is classified in one of four ways: passive line, passive marker, active marker, and rigid-body rotation. Passive line models assume that the mineral of interest behaves as a nonmaterial line or plane, and rotates without changing shape during deformation (March 1932). Passive marker behavior assumes that the mineral and the matrix have similar rheologic properties, so that the strain response (i.e. shape and orientation changes) of both the mineral and the matrix to a given stress is the same. Active marker behavior occurs when the mineral and the matrix have significantly different rheologic properties, such that the shape and orientation changes in the mineral during strain are a function of the viscosity contrast between the mineral and the matrix. Rigid-body models treat the mineral as a rigid ellipsoid in a viscously deforming matrix and are in effect an end member condition of active marker behavior. Like the passiveline model, rotation of the mineral occurs without shape change during deformation.

Studies of magnetic anisotropy in deformed rocks take two approaches to AMS-strain correlations. One approach is numerical modeling to simulate magnetic fabric development (e.g. Owens 1974, Richter 1992). These numerical models assume either passive-line or rigid-body (Gay 1968) behavior of the susceptibility carriers, and that the same susceptibility carriers were present throughout the deformation process. These models also either assume an initial, random orientation of the susceptibility carriers, or that the orientation of the initial fabric in the undeformed rock is known (e.g. Richter 1992). The second approach to AMS-strain correlations is more common and uses empirical correlations between conventional strain markers and the shape of the susceptibility ellipsoid (see review by Borradaile 1991). Empirical correlations are usually powerlaw relationships of the form $\left(k_{i}\right)=\left(\sqrt{\lambda_{i}}\right)^{a}$, where $k_{i}$ is a factor derived from the magnitude of the AMS axes and $\sqrt{\lambda_{i}}$ represents the principal strain (stretches). Although empirical correlations require no $a$ priori assumptions about the behavior of the AMS carriers, either passive-line or rigid-body rotation are again invoked to explain such correlations in mylonites (Goldstein 1980, Rathore et al. 1983, Goldstein \& Brown 1988, Ruf et al. 1988).

The plastic deformation of magnetite in the Parry Sound shear zone indicates that rigid-body and passiveline assumptions (explicit in the numerical models and implicit in the empirical models) cannot be used. We are therefore left with either the passive-marker or active-marker models to describe the strain response of magnetite (and AMS) in these rocks. To uniquely distinguish between these two models the rheologic contrast between magnetite and the matrix quartz and feldspar during mylonitization must be known. If the active-marker model is used, the shear zone would have to deform at strain rates either higher or lower than those of magnetite, depending on whether magnetite is stronger or weaker than the matrix. The strain rates calculated for magnetite are at the upper end of expected bulk strain rates in orogenic belts, so significantly higher strain rates in this shear zone are unlikely. Because magnetite is an accessory phase the matrix minerals will control the rheology of the shear zone. Considering the high temperatures in the shear zone, magnetite and the matrix minerals probably have comparable rheologies and thus deform at similar strain rates, which matches the inherent assumptions of the passive-marker model.

The AMS results from Site B, which accurately track the progressive foliation deflection from mylonite to ultramylonite, provide an opportunity to obtain an AMS-strain relationship. In the absence of composite (Housen et al. 1993) or inverse (Potter \& Stephenson 1988) magnetic fabrics, it is reasonable to assume that $k_{\max }$ parallels the $X$ axis of the finite strain ellipsoid (Borradaile 1991). The trend in AMS orientations is used to calculate shear strain for these mylonites: $\gamma=$ $\tan \Psi=\left(2 / \tan \left(2 \theta^{\prime}\right)\right)$ (Ramsay \& Huber 1983, p. 27), where $\theta^{\prime}$ is the angle between $k_{\text {max }}$ and the direction of shear (the shear-zone lineation), and $\gamma$ is the shear strain (Fig. 10). This model determines finite strain based on constant volume, plane-strain geometry. Shear strains calculated in this manner range from $\gamma=1-3$ in mylonite samples to $\gamma=9$ in the ultramylonites (Table 1).

The geometry of the strain model also predicts an increase in the strain ratio $R(X / Z)$ with increasing shear strain. Thus, the degree of anisotropy $P\left(k_{\max } / k_{\min }\right)$ 
(a)

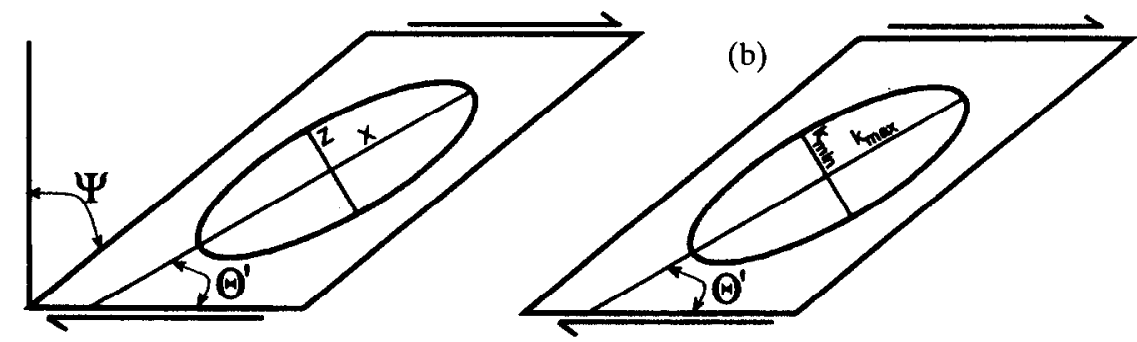

Fig. 10. Geometry of simple-shear models. Shear strain can be determined from the angle $\left(\Theta^{\prime}\right)$ between the $X$-axis of the strain ellipsoid and the direction of shear in the shear-zone foliation (a). The orientations of the AMS ellipsoid axes are generally parallel to the strain ellipsoid axes, so AMS orientations can also be used to determine shear strains using this method (b).

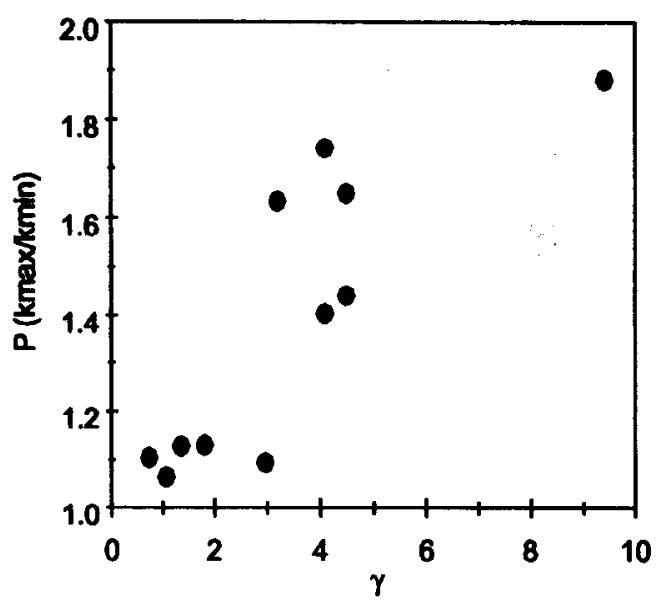

Fig. 11. Plot of degree of anisotropy $\left(P=k_{\max } / k_{\min }\right)$ of the AMS ellipsoid vs shear strain determined from AMS orientations.

should similarly increase with increasing shear strain if the shape of the AMS ellipsoid behaves as a passive marker. The mylonites and ultramylonites of Site B exhibit this trend, with $P$ increasing from 1.06 to 1.88 as the shear strain increases from 1 to 9 (Fig. 11). Since the shape of the AMS ellipsoid changes with increasing strain, an empirical correlation between strain and AMS axes is obtained given these assumptions.

Use of empirical AMS-strain correlations has not always been successful primarily because changes in AMS carrier minerals were not accounted for, or for over-extending the universality of such correlations (Borradaile 1988, 1991). It is, however, a valid approach for situations in which the AMS is carried by a single mineral throughout the deformation (such as in this study). The most successful approach is to correlate individual AMS principal values with individual principal strains (e.g. Hirt et al. 1988). The principal strains $(X, Z)$ are calculated from the shear strains at Site $B$ by $(X)=\left(\frac{1}{2}\left(\gamma^{2}+2+\gamma\left(\gamma^{2}+4\right)^{\frac{1}{2}}\right)\right)^{\frac{1}{2}}$ and $(Z)=\left(\frac{1}{2}\left(\gamma^{2}+2-\right.\right.$ $\left.\left.\gamma\left(\gamma^{2}+4\right)^{\frac{1}{2}}\right)\right)^{\frac{1}{2}}$ (Ramsay \& Huber 1983, p.30). The AMS principal values are represented by the magnetic parameter $M_{i}=\ln \left(k_{l} /\left(k_{\max } k_{\mathrm{int}} k_{\min }\right)^{1 / 3}\right)$. A least-squares fit between strain and AMS results, also assuming an initial isotropic fabric, yields a logarithmic relationship for both maximum and minimum axes: $M_{\max }=0.15 \ln (X)$, and $M_{\min }=0.13 \ln (Z)$ (Fig. 12). The correlation was evaluated using a statistical $t$-test, and found that the slope of the best-fit correlation line is non-zero at the $99.5 \%$ confidence level. The slight difference in

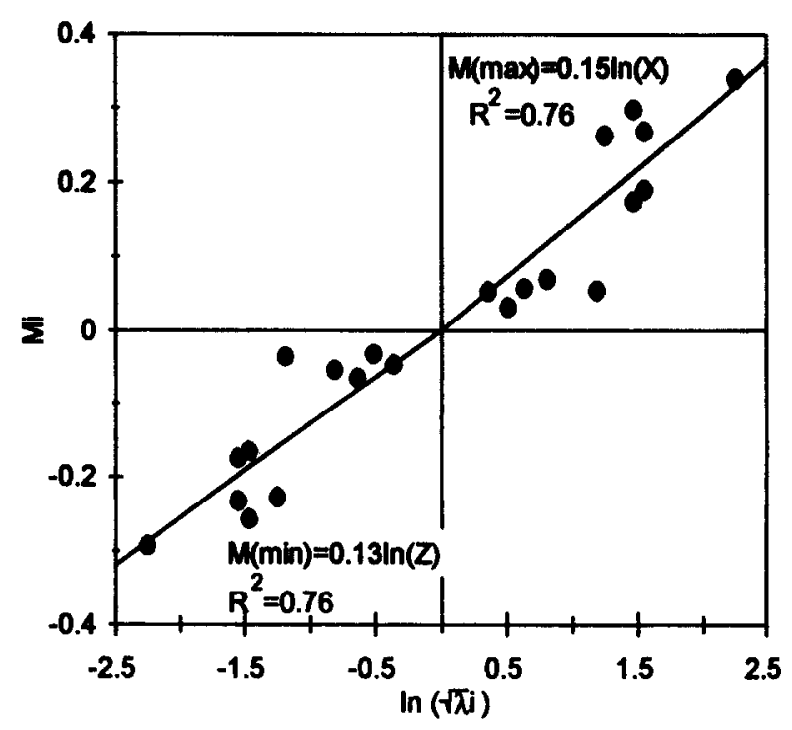

Fig. 12. Correlation plot between AMS axes and strain axes. The AMS results (vertical axis) are represented by the magnetic parameter $M_{i}=\ln \left(k_{i} /\left(k_{\max } k_{\mathrm{int}} k_{\min }\right)^{1 / 3}\right)$. The principal strains are plotted as $\ln (\sqrt{\lambda i})$ on the horizontal axis. Each axis (maximum and minimum strains and AMS) is correlated individually, with the best-fit (leastsquares) line and correlation coefficient given for each axis.

the correlation lines for the maximum and minimum axes is insignificant. This result is similar to the $M_{i}=$ $0.133 \ln \left(1+e_{i}\right)$ relationship in a magnetite-bearing mylonite obtained by Ruf $e$ t al. (1988). An alternative representation of an empirical AMS-strain relationship is obtained by correlating $\ln (P)$ and $\ln (R)$ (Fig. 13), which gives a relationship of the form $\left(k_{\max } / k_{\min }\right)=$ $(X / Z)^{a}$, where in this case $a=0.14$. Given the similar trend in AMS ellipsoid shapes with increasing deformation in Sites A and B (compare Figs. 8d \& f) and the identical magnetic mineralogy and lithology at the two sites, the empirical AMS-strain correlation determined at Site B can now be applied to the Site A mylonite and ultramylonite samples. Shear strains estimated from this correlation range from $\gamma=1$ in the least anisotropic mylonite to $\gamma=13$ in the most anisotropic ultramylonite (Table 1).

Such high values of strain may not initially be expected from AMS analysis, as near-perfect alignment of susceptibility carriers by rotation (fabric saturation) is assumed to occur at much lower ( $\mathrm{ca} .80 \%$ shortening) strains (Borradaile 1991). Indeed, using a rigid-body rotation model to numerically describe the strain 


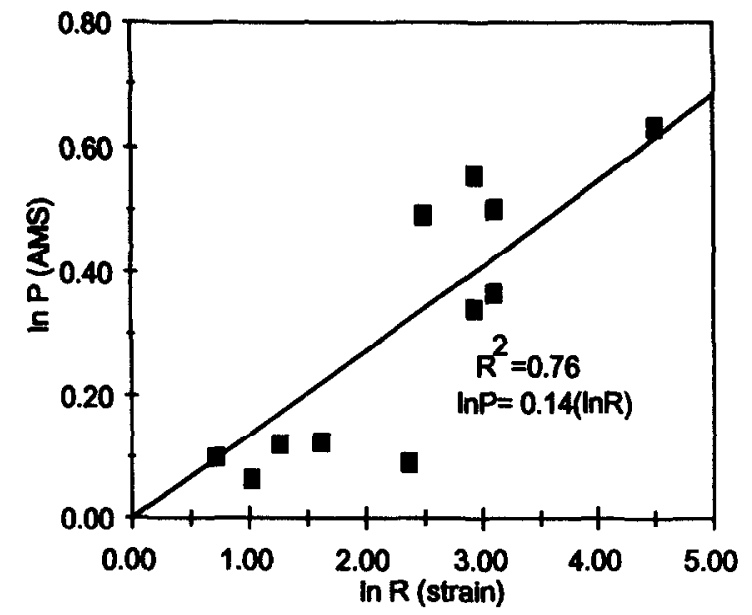

Fig. 13. Correlation piot between $\ln (P)$ and $\ln (R)$, where $P=\left(k_{\max } / k_{\min }\right)$ and $R=(X / Y)$. A relationship $\ln (P)=0.14 \ln (R)$ is obtained via least-squares best fit of the data.

response of magnetite, 'maximum' shear strains of $\gamma=3$ were calculated for these rocks from the AMS data in Table 1 (Housen et al. 1991). Fabric saturation occurs in situations when the single-grain AMS is constant. This is the case for all paramagnetic silicates, ferrimagnetic sulfides and hematite, whose single-grain AMS is controlled by their crystallography rather than grain shape. Fabric saturation will also occur in magnetite-dominated rocks when magnetite behaves as a rigid particle. However, because the single grain AMS of magnetite is controlled by its shape rather than its crystal axes, changes in the shape of magnetite grains will result in corresponding changes in the single grain AMS. If plastically-deforming magnetite grains develop an increasing degree of shape anisotropy with increasing deformation, an AMS fabric that is controlled by magnetite will not saturate at high strains until a steady-state grain shape is attained. The predicted crystal-plastic deformation mechanism of magnetite in the Parry Sound shear zone therefore explains the measured high strains obtained by AMS in these rocks. Thus, studies of AMS in other mid- to lower-crustal shear zones that are dominated by magnetite can yield highly sensitive rock fabric determinations, and estimates of the strain state are possible provided that the deformation mechanism(s) are adequately known.

Acknowledgements--Research support was provided by NSF grant EAR 91-19196 to BvdP, and research grants from the Geological Society of Anerica, Sigma Xi, and the UM-Scott Turner Research Fund (Housen). Work conducted at the Institute for Rock Magnetism was made possible by the Keck Foundation and NSF. We thank G. J. Borradaile and A. M. Hirt for their constructive reviews of this paper, and J. P. Busch, D. R. Peacor, C. Richter, J. Stamatakos, and R. Van der Voo for comments and suggestions during the course of our work.

\section{REFERENCES}

Atkinson, B. K. 1977. The kinetics of ore deformation: its illustration and analysis by means of deformation-mechanism maps. Geol. För. Stockh Förh. 99, 186-197.

Blundy, J. D. \& Holland, T. J. B. 1990. Calcic amphibole equilibria and a new amphibole-plagioclase geothermometer. Contrib. Mineral. Petrol. 104, 208-224.

Borradaile, G. J. 1988. Magnetic susceptibility, petrofabrics and strain. Tectonophysics 156, 1-20.
Borradaile, G. J. 1991. Correlation of strain with anisotropy of magnetic susceptibility (AMS). Pure \& Appl. Geophys. 135, 1529.

Borradaile, G. J. \& Mothersill, J. S. 1984. Coaxial deformed and magnetic fabrics without simply correlated magnitudes of principal values. Phys. Earth \& Planet. Interiors 35, 294-300.

Castle, J. E. \& Surman, P. L. 1967. The self-diffusion of oxygen in magnetite. Techniques for sampling and isotopic analysis of micro quantities of water. J. Phys. Chem. 71, 4255-4259.

Cosca, M. A., Essene, E. J. \& Bowman, J. R. 1991. Complete chemical analyses of metamorphic hornblendes: implications for normalizations, calculated $\mathrm{H}_{2} \mathrm{O}$ activities, and thermometry. Contrib. Mineral. Petrol. 108, 472-484.

Davidson, A., Culshaw, N. G. \& Nadeau, L. 1982. A tectonometamorphic framework for part of the Grenville Province, Ontario. Geol. Surv. Pap. Can. 82-1A, 175-190

Etheridge, M. A. 1983. Differential stress magnitudes during regional deformation and metamorphism: upper bound imposed by tensile fracturing. Geology 11, 231-234.

Fleet, M. E. 1981. The structure of magnetite. Acta Cryst. 37, 917-920.

Gay, N. C. 1968. The motion of rigid particles embedded in a viscous fluid during purc shear deformation of the fluid. Tectonophysics 5 , 81-88.

Goldstein, A. G. 1980. Magnetic susceptibility anisotropy of mylonites from the Lake Char mylonite zone, southeastern New England. Tectonophysics 66, 197-211.

Goldstein, A. G. \& Brown, L. L. 1988. Magnetic susceptibility anisotropy of mylonites from the Brevard Zone, North Carolina, U.S.A. Phys. Earth \& Planet. Interiors 51, 290-300.

Gower, R. J. W. \& Simpson, C. 1992. Phase boundary mobility in naturally deformed, high-grade quartzofeldspathic rocks: evidence for diffusional creep. J. Struct. Geol. 14, 301-314.

Graham, C. M. \& Powell, R. 1984. A garnet-hornblende geothermometer: calibration, testing, and application to the Pelona Schist, Southern California. J. Metamorphic Geol. 2, 13-31.

Hewitt, D. F. 1967. Geology and mineral deposits of the Parry SoundHuntsville area. Rep. 52, Ontario Dept. Mines, Toronto.

Hirt, A. M., Lowrie, W., Clendenen, W. S. \& Kligfield, R. 1988. The correlation of magnetic anisotropy with strain in the Chelmsford Formation of the Sudbury Basin, Ontario. Tectonophysics 145, 177189.

Housen, B. A. 1994. Quantification of Mincral Fabrics in Various Deformed Rocks Using Magnetic Anisotropy. Unpublished Ph.D. thesis, University of Michigan, Ann Arbor.

Housen, B., Richter, C. \& van der Pluijm, B. 1991. Finite strain modeling of magnetic anisotropy results from an anorthosite ductile shear zone. Eos. Trans. Am. Geophys. Union 72, 98.

Housen, B. A., Richter, C. \& van der Pluijm, B. A. 1993. Composite magnetic anisotropy fabrics: experiments, numerical models, and implications for the quantification of rock fabrics. Tectonophysics 220, 1-12.

Indares, A. \& Martignole, J. 1985. Biotite-garnet geothermometry in granulite-facies rocks-evaluation of equilibrium criteria. Can. Mineralogist 23, 187-193.

Jackson, M., Gruber, W., Marvin, J. \& Banerjee, S. K. 1988. Partial anhysteretic remanence and its anisotropy: applications and grain size-dependence. Geophys. Res. Lett. 15, 440-443.

Knipe, R. J. 1989. Deformation mechanisms-recognition from natural tectonites. J. Struct. Geol. 11, 127-146.

Kohn, M. J. \& Spear, F. S. 1990. Two new geobarometers for garnet amphibolites, with applications to southeastern Vermont. Am. Miner. 75, 89-96.

March, A. 1932. Mathematische Theorie der Regelung nach der Korngestalt bei affiner Deformation. Z. Kristallogr. 81, 285297.

Mooney, H. M. \& Bleifuss, R. 1953. Magnetic susceptibility measurements in Minnesota. Part II: analysis of field results. Geophysics 18 , 383-393.

O'Hara, K. 1990. State of strain in mylonites from the western Blue Ridge province, southern Appalachians: the role of volume loss. $J$. Struct. Geol. 12, 419-430.

Owens, W. H. 1974. Mathematical model studies on factors affecting the magnetic anisotropy of deformed rocks. Tectonophysics 24, 115131.

Pfiffner, O. A. \& Ramsay, J. G. 1982. Constraints on geological strain rates: arguments from finite strain states of naturally deformed rocks. J. geophys. Res. 87, 311-321.

Potter, D. K. \& Stephenson, A. 1988. Single-domain particles in rocks and magnetic fabric analysis. Geophys. Res. Lett. 15, 1097 1100 . 
Pownceby, M. I., Wall, V. J. \& O'Neill, H. St. C. 1991. An experimental study of the effect of $\mathrm{Ca}$ upon garnet-ilmenite $\mathrm{Fe}-\mathrm{Mn}$ exchange equilibria. Am. Miner. 76, 1580-1588.

Ramsay, J. G. \& Huber, M. I. 1983. The Techniques of Modern Structural Geology, Vol. 1, Strain Analysis. Academic Press, San Diego, California.

Rathore, J. S., Courrioux, G. \& Choukroune, P. 1983. Study of ductile shear zones (Galicia, Spain) using texture goniometry and magnetic fabric methods. Tectonophysics $98,87-109$.

Richter, C. 1992. Particle motion and the modelling of strain response in magnetic fabrics. Int. J. Geophys. 110, 451-464.

Ruf, A. S., Naruk, S. J., Butler, R. F. \& Calderone, G. J. 1988. Strain and magnetic fabric in the Santa Catalina and Pinaleno Mountains metamorphic core complex mylonite zones, Arizona. Tectonics 7 , 235-248.

Schmid, S. M. 1982. Microfabric studies as conditions of deformation mechanisms and flow laws operative in mountain building. In: Mountain Building Processes (edited by Hsu, K. J.). Academic Press, London, 95-110.

Schmid, S. M. 1989. Episodes in Alpine orogeny. Geol. Soc. Am. Abs. w/Prog. 21, A28.

Spear, F. S. 1991. On the interpretation of pcak metamorphic tcm- peratures in light of garnet diffusion during cooling. J. Metamorphic Geol. 9, 379-388.

Spear, F. S. \& Kimball, K. 1984. RECAMP-A FORTRAN IV program for estimating $\mathrm{Fe}^{3+}$ contents in amphiboles. Comput. \& Geosci. 10, 317-325.

Tuccillo, M. E., Mezger, K., Essene, E. J. \& van der Pluijm, B. A 1992. Thermobarometry, geochronology and the interpretation of $P-T-t$ data in the Britt Domain, Ontario Grenville orogen, Canada. J. Petrol. 33, 1225-1259.

Tullis, J. 1983. Deformation of feldspars. In: Feldspar Mineralogy (2nd edition) (edited by Ribbe, P. H.). Min. Soc. Am. Rev. Mineralogy 2, 297-323.

Tullis, J. A. \& Yund, R. A. 1985. Dynamic recrystallization in feldspar: a mechanism for ductile shear zone formation. Geology 13, 238-241. van Breeman, O., Davidson, A., Loveridge, W. D. \& Sullivan, R. W. 1986. U-Pb zircon geochronology of Grenville tectonites, granulites and igneous precursors, Parry Sound, Ontario. Spec. Pap. geol. Assoc. Can. 31, 191-207.

White, J. C. \& Mawer, C. K. 1986. Extreme ductility of feldspars from a mylonite, Parry Sound, Canada. J. Struct. Geol. 8, 133-143.

Wones, D. R. \& Eugster, H. P. 1965. Stability of biotite: experiment, theory, and application. Am. Miner. 50, 1228-1272. 